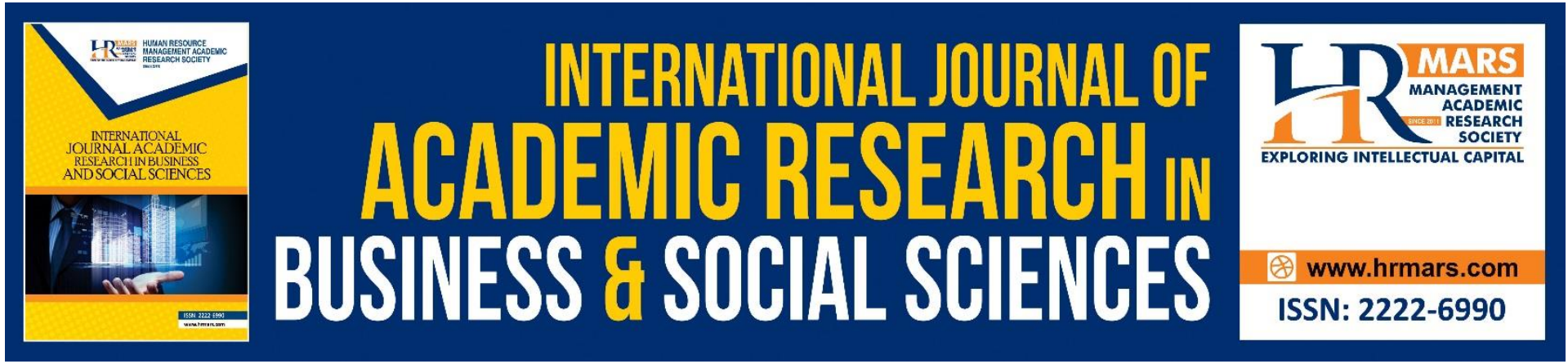

\title{
Oral Communication Strategies Preferences in Arabic Debate among Non-Arabic Speakers
}

Ahmad Syahmi Mohamed, Nik Farhan Mustapha, Ab Halim Mohamad, Rosya Izyanie Shamshudeen, Nurazan Mohmad Rouyan

To Link this Article: http://dx.doi.org/10.6007/IJARBSS/v11-i9/10758 DOI:10.6007/IJARBSS/v11-i9/10758

Received: 10 July 2021, Revised: 12 August 2021, Accepted: 27 August 2021

Published Online: 07 September 2021

In-Text Citation: (Mohamed et al., 2021)

To Cite this Article: Mohamed, A. S., Mustapha, N. F., Mohamad, A. H., Shamshudeen, R. I., \& Rouyan, N. M. (2021). Oral Communication Strategies Preferences in Arabic Debate among Non-Arabic Speakers. International Journal of Academic Research in Business and Social Sciences, 11(9), 131-151.

Copyright: @ 2021 The Author(s)

Published by Human Resource Management Academic Research Society (www.hrmars.com) This article is published under the Creative Commons Attribution (CC BY 4.0) license. Anyone may reproduce, distribute, translate and create derivative works of this article (for both commercial and non-commercial purposes), subject to full attribution to the original publication and authors. The full terms of this license may be seen at: http://creativecommons.org/licences/by/4.0/legalcode

Vol. 11, No. 9, 2021, Pg. 131 - 151

Full Terms \& Conditions of access and use can be found at http://hrmars.com/index.php/pages/detail/publication-ethics 


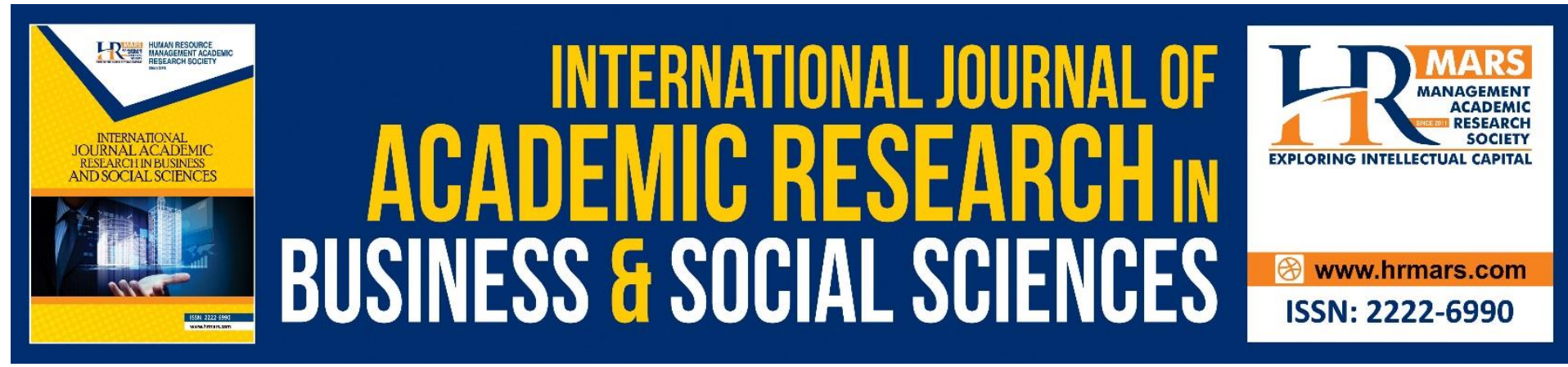

\title{
Oral Communication Strategies Preferences in Arabic Debate among Non-Arabic Speakers
}

\author{
Ahmad Syahmi Mohamed', Nik Farhan Mustapha², Ab Halim \\ Mohamad $^{3}$, Rosya Izyanie Shamshudeen ${ }^{4}$, Nurazan Mohmad \\ Rouyan 5 \\ 1,2,3 Faculty of Modern Languages \& Communication, Universiti Putra Malaysia, 43400
} Serdang, Selangor, Malaysia, ${ }^{4}$ Faculty of Arts \& Social Sciences, Universiti of Malaya, 50603 Kuala Lumpur, Malaysia, ${ }^{5}$ Faculty of Languages and Communication, Universiti Sultan Zainal

Abidin (UniSZA), Kampus Gong Badak, 21300 Kuala Terengganu, Terengganu, Malaysia

Email: farhan@upm.edu.my

\begin{abstract}
Debate is a language learning activity that requires the debater to choose effective oral communication strategies to weaken the opponent. Thus, this study was conducted to identify the oral communication strategies preferences among Arabic language debaters consisting of non-native speakers. The respondents were the champions of the Higher Education Institutions level debate, while the data were obtained from video recordings of the debate competition and interviews. The data were then analysed using Communication Strategies Theory. The results showed that the debaters preferred the strategies of message abandonment, topic avoidance and appeal for assistance when short of time and approximation and word coinage when faced with language constraints. Literal and contextual translation and language switch strategies were chosen for debate preparations, while circumlocution and mime strategies were preferred for reinforcing arguments. A new strategy was also found, which is named as repetition strategy. The findings proved that the preference of these strategies help the debaters to organize ideas, articulate and confidently present arguments despite their own shortcomings and interruptions from opponents. This study contributes to the structure of debate training activities focused on more systematic oral communication strategies that can be applied to debaters in Arabic language learning classes.
\end{abstract}

Keywords: Communication Strategies, Oral Communication, Debate, Arabic Debate, NonArabic Speakers

\section{Introduction}

Nowadays, debates are considered as one of the important learning activities for students in learning a language, either in their native language or a foreign one. This is because of the way debating activities are conducted systematically in a language class which can improve students' interaction, develop critical thinking skills, train them in using appropriate course contents during debating, as well as improve skills in reading, writing, listening and speaking 
(Zare \& Othman, 2015). In terms of language acquisition, especially for non-native debaters, they would need to prepare the target language before presenting their arguments. It starts with a discussion on the proposal for the topic to be debated, brainstorming all important contents, arguments, and questions that might be asked by the opponents, so that the judges would be able to declare victory for them and not their opponents (Morse, 2011). In the training session, the debating coach will teach them approaches related to the debating process, and train them on the techniques of constructing each content and description of speech with the appropriate language, so that effective communication skills can be highlighted along with an interesting style of argumentation (al-Hujuri, 2019).

Initially, debates were only introduced in the learning of native languages, but this later included foreign language learning such as the Arabic language in Malaysia (al-Hujuri, 2019). Since then, several studies have been conducted on debating which has brought on the issue of pronunciation of letters among debaters. Debaters often make mistakes in pronouncing the letters that are not found in their native language which shows lack of fluency during debates (Radzi et al., 2015). Recent studies showed that debates successfully help in improving fluency in speaking, as almost $80 \%$ of the activities in debates emphasize the aspect of pronunciation. The main factor that contributes towards this improvement is because debating emphasizes on time management, meaning-focused activities, planning and preparation, and repeated practice by the debaters (Abu Bakar \& Alias, 2017; Alias, 2018). In fact, debaters who strongly believe in the benefits of debating activities, and those who have good emotional control as well as high self-esteem, will be able to master speaking well, not only during debating, but also in language learning sessions as a whole (Omar, 2015).

In terms of language acquisition, debates are believed to have a very related and positive relationship in improving the language proficiency of students, especially in speaking. This means that this skill can be improved when they participate in debating activities, either at school or at university level (Satria, 2017). It not only reinforces the correct and accurate pronunciation of a debater (Radzi et al., 2015; Abu Bakar \& Alias, 2017; Alias, 2018), but also improves the level of fluency, argument construction skills, quick understanding, and ability to argue with accurate facts (al-Hujuri, 2009). Their level of readiness to speak in Arabic and linguistic confidence level also increase compared to those who do not engage in debates. These positive results are based on the characteristics of pushed output activity in the debate itself, such as student's exposure to a variety of topics, communicative tasks, group activities, standards of performance, time planning, and repetition (Abu Bakar \& Alias, 2017; Alias, 2018). As a result, debates assist in increasing a student's overall level of Arabic proficiency (Omar, 2015; Alias, 2018; Che Haron et al., 2010). Therefore, students, especially at university level are strongly encouraged to participate in Arabic debates in order to improve their speech level and fluency (al-Hujuri, 2019; Che Haron, et al., 2010).

It is a well-known fact that debates involve several processes which begin from preparation right through to the day of the debating competition itself. The initial process is crucial in helping debaters to speak well throughout the event (Che Haron, et al., 2010). The discussion stage could take a long time as the debaters would need to obtain sufficient vocabulary and style of language appropriate to each topic and presentation (al-Hujuri, 2019). Hence, planning is an important element in improving one's language skills (Mohamad, Embi \& Nik Yusoff, 2010). In presenting an argument during a debate, a debater should start with a 
definition or primary point, followed by descriptions and examples. Finally, a conclusion should be made by making a connection to what has been said (Simon, 2010). This form of elaboration of the argument will help debaters to organise information to be presented more concisely, accurately and precisely, in order to attract the attention of the jury and the audience. During the debate itself, there are several processes that need to be carried out, such as when to throw arguments, make interjections, turn off the arguments of opponents, and so on (al-Hujuri, 2019). All of these processes undoubtedly require debaters to have robust and effective strategies to help them speak fluently while presenting clear and critical ideas.

\section{Oral Communication Strategies and Acquisition of Speaking Skills}

Based on previous studies, Arabic speaking skills in Malaysia are considered a difficult skill to master with the level of proficiency remaining at a moderate or weak level (Abd Rahman et al., 2012; Asbulah et al., 2020). Weaknesses in mastering this skill have become a major problem among Malaysian students in learning the Arabic language, with some unable to complete their studies within the prescribed period (Che Haron et al., 2010). In fact, 70\% of Arabic language students in higher learning institutions in Malaysia are unable to speak Arabic well (Daud \& Abdul Pisal, 2014). As a result, they either choose not to speak or speak very little Arabic in or out of their classes (Abd Rahman et al., 2012; Asbulah et al., 2020). In the context of second language learning, this can be a disappointment when a student is unable to speak in the target language after graduation (Satria, 2017).

Studies have shown that mastery of good Arabic speaking skills is closely related to the use of effective strategies (Hamzah, 2018). It is proven that applying language learning strategies and self-practice oral communication can help students to improve their speaking skills (Arshad \& Abu Bakar, 2015). Without the right strategy, a student would not be able to choose the correct vocabulary nor organise ideas well in oral communication. In fact, the use of various language learning strategies is able to further enhance the quality of spoken utterance (Che Haron et al., 2010). It has been pointed out that the criteria to evaluate the speaking ability of an Arabic language student include vocabulary, phonetics, sentence structures, and communication strategies (Ismail@Yaakub, Che Mat \& Pa, 2012). This shows that a student's language learning strategies play an important role in ensuring that they are able to interact well. For example, when facing lexical constraints in ordinary speech, students frequently use native language-based strategies such as code-switching and literal translation. They also use meaning or sound approximation strategies between foreign language learned and their mother tongue, new word creation, as well as repetition strategies. Studies have also found that students apply the cooperation appeal strategy directly. In situation where lexical deficiency occurs during oral communication, they will use avoidance strategies (Aladdin, 2012). Thus, it means that students not only know how to use strategies, but are aware of how strategies could be used effectively in the speaking process, so that the message to be conveyed can be understood by the listener, regardless of the form of speech including debates.

In the context of debates, debaters need to have an effective delivery strategy. They would need to come up with various strategies to ensure that arguments presented are easy to understand, and are convincing and persuasive enough to win over the jury (Kiram \& Abdul Rahim, 2018). Generally, students who participate in Arabic debates are fluent in the language. This proficiency is measured by their capability in presenting the arguments, criticism, and also answering interjections (Samah et al., 2013). However, previous studies 
related to Arabic debates have only highlighted that debate is the most effective strategy and recommended activity in the Arabic language learning classroom to improve speaking skills, without providing details related to the oral communication strategies chosen by the debater himself in the face of opponents (al-Hujuri, 2019). Thus, this study is conducted to analyse the oral communication strategies preference of non-Arabic-speaking debaters during debates.

\section{Research Design}

The respondents of this research comprised three students who represented the team which won the Arabic language debate event at the university level. The data collection process began by recording their final preparations before the commencement of the final round of the debate competition. The recording then continued throughout the final round until the end of the competition. The recording was then closely scrutinised by the researcher to identify the strategies adopted by the debaters. It encompassed strategies in the form of speech as well as movement and mime. Next, the interview process was conducted. Throughout the interview process, the researcher posed several questions regarding the oral communication strategies which was analysed by scrutinising the video recording to obtain confirmation and details regarding its use throughout the competition. The interview sessions were conducted in the Malay language and the translation of the responses is presented in a condensed version.

As a result of the data from the video recordings and interview transcriptions, the Communication Strategies Theory pioneered by Tarone (1980) was selected for the data analysis process. This theory is based on the taxonomy founded on three main strategies, which are avoidance, paraphrase, and transfer. Under each of these main strategies, there are other strategies such as message abandonment and topic avoidance under avoidance strategies, approximation, word coinage and circumlocution under paraphrase strategies, as well as literal translation, language switch, appeal for assistance, and mime under transfer strategies. Figure 1 below presents the taxonomy as well as the sub strategies in detail.

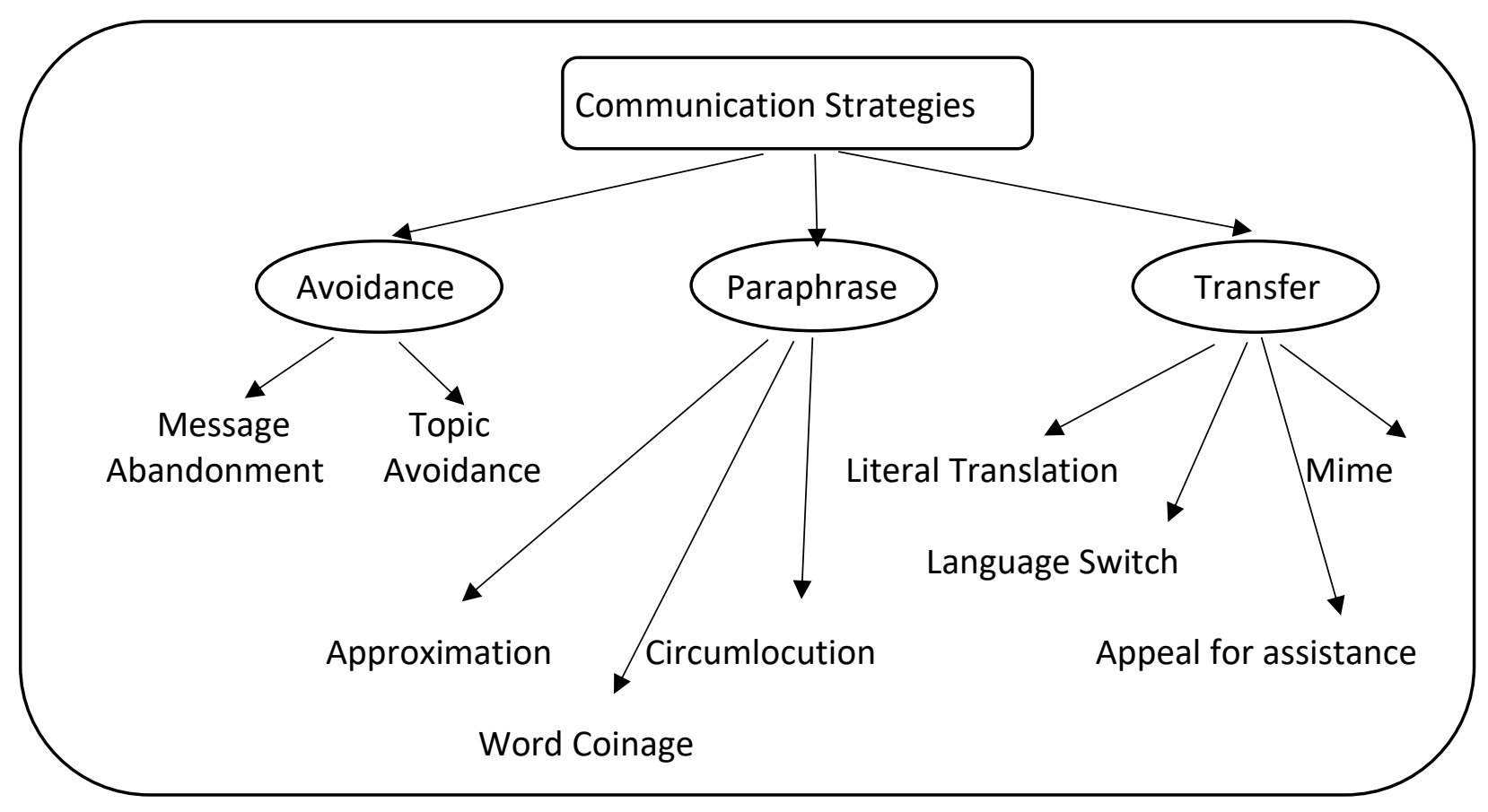

Figure 1 Communication Strategies (Tarone, 1980) 


\section{Analysis and Discussion}

The results of the analysis found that the debaters used three main strategies as outlined by Tarone (1980), which are avoidance, paraphrase and transfer. However, this research has found an additional main strategy which was often chosen by the debaters during the debate; that is the repetition strategy. For each of these main strategies, there are various sub strategies that will be reviewed in detail, as follows.

\section{1) Avoidance Strategy}

Based on the analysis of the oral communication strategies, this avoidance strategy can be divided into two parts, which are message abandonment and topic avoidance. Findings show that the message abandonment strategy was chosen during the debate when the opposing team raised a question or an issue, but the debater was unable to provide the answer required and hence the issue was left without a response. Whereas the topic avoidance strategy is centred around a message that is conveyed by the opposing team, but the debater adopted several techniques to avoid answering the question by giving an inaccurate answer and not delving into the true issue raised.

\section{a. Message Abandonment}

In debate, interruption means a process by the opposing team to question the credibility of the argument or explanation presented by a debater. During this time, the debater is given the option whether to accept or reject every question put forward by the opposing team. Hence, the debating party will frequently opt for the message abandonment strategy when faced with interruptions from the opposing team.

In this research, the results of the video analysis showed that the first respondent was interrupted at minute 05.35 by the opposing team (MV_5561: R1). The respondent appeared to turn silent and unable to reply, hence he avoided answering the question by saying that his colleague will address the question.

The second respondent also abandoned the interruption that the opposing team tried to do twice, that is at minute 01.35 and minute 01.58 (MV_5562: R2). When interviewed regarding the situation, the respondent gave the following response:

"... apabila ada mudakholah [celahan] daripada pihak lawan.. tapinya.. saya rasa, saya kena habiskan dulu apa yang saya nak cakap. Dan lepas ni, kalau nak cakap, cakaplah..." (U22: R2)

["... when there is an mudakholah [interruption] from the opposing team.. but.I feel, I should finish what I would like to say first. And then after this, if wish to speak, go ahead..."]

This means the respondent felt a need to finish presenting the content that he wanted to put forth first, and if there was still time, he would respond to the interruption.

The same was also admitted by the first respondent when he said:

"Saya mengikut keadaan yang sesuai, kalau saya rasa saya dah habis hujah ni, saya boleh bagi. Kalau saya belum habis, saya akan tangguhkan..." (U23: R1) ["I go according to the right moment, if I feel I have finished this argument, then I will allow. If I haven't finished, I will postpone it..."] 
The third respondent also faced the same situation when he was pressed by the opposing team with several interruptions. However, he gave the excuse that the time given for him to finish his speech was running out. Therefore, he abandoned that message.

The respondents also admitted that they felt rather nervous when interrupted by the opposing team, especially when thinking about their team competing in the final stage of the competition, as the response provided by the third respondent:

"Saya rasa masa tu, saya pun berdebar." (U24: R3)

["I think at that time, I was also nervous."]

This feeling is found to be the main factor which caused the debaters to choose the message abandonment strategy.

The results of the analysis showed that message abandonment is seen as one of the dominant strategies practised by each respondent of this research to reject any interruption. It is also connected to the feeling of nervousness and fear, which are normal feelings to have in every debating event as this activity requires students to speak spontaneously, while systematically arranging the deluge of ideas that come to their mind.

To summarise, this message abandonment strategy was adopted by the respondents not only because they were unable to answer the question presented, but also due to the limited time factor as each debater was only given seven minutes to present their argument. The atmosphere of the final round of the debate competition was also a main factor for them to include this strategy as part of their communication process when the feeling of nervousness and fear took hold of them. By using this strategy during the debate, it can avoid interruptions to their train of thought which would prevent them from continuing to present their arguments.

\section{b. Topic Avoidance}

The results of the analysis performed on the recording data showed that the topic avoidance strategy was clearly displayed when the second debater tried to reply to the question raised by the opposing team on two issues, which were آلية (criteria) and ضمان (guarantee). However, the second respondent only replied for the word ضمان (guarantee) and avoided the topic relating to آلية (criteria). This situation can be seen when the second respondent was debating at minute 01.18 (MV_5562: R2). When this matter was raised during the interview, the respondent stated:

"Sebenarnya bila kitorang tak faham mudakholah [celahan] tu, ... kami tak tahu perkataan aaliat tu apa. Tapi kami faham yang last sekali je... Dhommaan..." (U30: R2)

["Actually when we don't understand the mudakholah [interruption], ... we don't know what the word aaliat means. But we only understand the last one ... Dhommaan..."]

Based on the above statement given by the respondent, it can be understood that Arabic language debaters also experience some problems in understanding every word of the opponent, especially when the question given contains words that have not been heard 
before or used in previous debates. By only responding to the meaning of the word 'dhomman', he was able to avoid answering the whole topic presented by the opposing team. This strategy seems effective in debate which require quick ideas and critical thinking so that the flow of the speaking process is not interrupted.

The respondent also admitted that in several circumstances, they did not quite understand the question put forth by the opposing team. Thus they worked hard to guess the overall meaning of the question using the several words that could be understood, as in the following statement:

"Macam kami dalam debat ni, ... tak semua perkataan kami tahu aa, tapi bila ada mafhum [faham] certain perkataan, kita boleh expect aa, sebab takkan nak diam je kan. Biasanya kami ambik satu perkataan dan teka apa agaknya dia nak cakap. Tapi memang secara jujurnya apa yang tepatnya yang dia nak sebenarnya, tak tahu" (U31: R3)

["For us in this debate, ... not all the words we know, but when there is mafhum [understand] certain words, we can expect, because we cannot just keep quiet. Usually we will take one word and guess what they are trying to say. But honestly what exactly they want actually, don't know"]

Here it is clear, that the skills of the debater in choosing this strategy managed to avoid interruption to the flow of their debate presentation, although the question itself was not given a proper response.

This topic avoidance strategy is also used by giving the response that the opponent understand the matter himself based on the arguments presented. This happens when they are short of time to give a response. Hence the respondent stated:

"So macam kita kejar masa, so saya cakap aa, saya cakap kat dia, al ijaabah athna' al-munazarah [jawapan diberikan semasa perdebatan], saya cakap kat dia camtu je" (U34: R3)

["So it's like we are running out of time, so I will say to him, al ijaabah athna' al-munazarah [the answer is given during the debate], I will just say that to them"]

The use of the phrase "al-ijabah athna' al-munazarah" implies that the respondent is asking the opponent to obtain the answer to the question raised through the arguments in the debate. Analysis shows that this strategy is very effective for the debater to stabilise their presentation so as not to be interrupted by complicated questions from the opposing team.

In conclusion, the topic avoidance strategy is among the selected strategies by the respondents when debating. The use of this avoidance strategy shows that the debaters have taken the effort to answer the question raised by the opponent although in reality they are facing problems understanding the question. It is also used as a systematic step to ensure that every idea and debate content can be conveyed within the time allocated 
and that there are no problems in terms of fluency and smoothness, as well as not being interrupted by the opposing team.

\section{2) Paraphrase Strategy}

The paraphrase strategy is the restatement of a phrase or text using one's own language. A debater will definitely be continually faced with various texts that need to be summarised or reworded so that the information required can be conveyed in a language that is clear and easier to understand. Therefore, this strategy becomes the choice of debaters for starting their presentation.

The data that was analysed from the recording data and the interview data found that this main strategy was selected by the respondents and used in the form of approximation, word coinage and circumlocution strategies.

\section{a. Approximation}

The findings of this research showed that this approximation strategy was used in two circumstances, which are when having problems pronouncing a word, and also when faced with limitations in understanding the meaning of the interruption, question as well as content of the speech put forth by the opponent. The breakdown of both circumstances are as follows:

\section{i- $\quad$ Approximation in terms of word or terminology}

As a debater who is a non-native Arabic speaker, the debater will usually obtain the information for his arguments from sources of references which use three main languages, which are Malay language, English language as well as Arabic language. These three languages are the main lingua franca to obtain various sources of information that must be understood by an Arabic language debater, that sometimes it causes difficulties for him to say several words or phrases found. In this situation, the approximation strategy is the alternative choice of the debater.

For example, in this competition, the debater faced problems to pronounce the English word that had been arabicised; which is البكالوريوس (al-bakālūriyus) or in the Malay language means Bachelor Degree. This word is an English word which has been arabicised that originated from the word 'Bachelor'. The results of the analysis showed that the three respondents were unable to say this word accurately so much so that that it disrupted their presentation. This situation can be seen in the video recording of their presentation when the first respondent said it as al-bikāluriyus in minute 02.30 (MV_5561: R1), the second respondent pronounced it as al-bikloriyus in minute 00.44 (MV_5562: R2), whereas the third respondent al-bakeloris in minute 00.56 (MV_5563: R3).

During the interview process, they admitted that they were unable to pronounce the word correctly, so the strategy of approximating the pronunciation was chosen so as not to disrupt the quality of their presentation.

"Saya agak-agak je. Saya cakap je apa yang saya.., saya rasa kan.." (U8: R1)

["I just guessed. I simply said what I felt..."] 
The respondent also stated that the main cause of the inconsistent pronunciation is due to lack of preparation before the debate. This was admitted by one of them when they stated: "Tajuk ni, kitorang sebenarnya tak prepare pun, so perkataan tu, bila sebelum tu kitorang ada cakap-cakap dengan ustaz, ustaz bagi perkataan tu secara bertulis, pastu kitorang tau cara sebut tu, kitorang tau in English je, bachelor, soh.. nak sebut in Arab tu, tak tahu macam mana, cara sebutan yang betulnya. Haa macam tu.." (U58: R3)

["This topic, we actually didn't prepare for it, so that word, we spoke with the ustaz, the ustaz gave that word in writing, so we know how to say it, we only know in English, bachelor, so to say it in Arabic, don't know how, the correct pronunciation..."]

According to the respondents of the research this situation often happens during debates. Hence the approximation strategy is adopted so that the pronunciation made is almost the same as the actual pronunciation. Selecting this strategy greatly assisted them in ensuring the smoothness of the debate flow without any interruptions

\section{Approximation in Understanding What is being Said by the Opponent}

During the debate, a situation took place whereby the debaters were unable to fully understand the content put forth by the opposing team. In this research, the approximation strategy was used whenever that situation arose. The debater approximated the meaning based on several words which could be understood to understand the overall argument of the opponent. The following is a response by the respondent regarding this matter:

"Biasanya kami ambik satu perkataan dan teka apa agaknya dia nak cakap" (U31: R3) ["Usually we will take one word and guess what he is trying to say"]

This finding showed that this strategy is often chosen when the respondent is experiencing linguistic constraints during the debate, either in terms of pronunciation or understanding.

\section{b. Word Coinage}

Word coinage does not mean that one creates a new word, but it is a strategy in the oral communication process which is used by the one delivering the information by using other words to describe the meaning of that which is to be conveyed.

Based on the results of the analysis on the data collected the respondent gave a response based on the use of the word coinage strategy during the debate. They used a word that is more or less the same with what was required. This situation can be seen in the video which was recorded when the respondent used the word ليس قويا (not strong) while presenting his argument in minute 02.57 (MV_5561: R2). Actually, the word ضعيف (da'îf) which means 'weak' is more suitable to be used. The selection of this strategy was made for the following purpose, as stated by the respondent:

"...dalam masa yang sama kita dapat menghafal murodif [sama maksud] yang berkaitan dengan perkataan $t u$, ...aa dia... membantu kita untuk menjelaskan bagi orang yang tak faham satu perkataan tu, dengan satu perkataan yang lain dan kita tambahkan." (U15: R1)

["...at the same time we can memorise murodif [same meaning] which is related to that word, ... it helps us to clarify for those who do not understand that one word, with another word and we elaborate."] 
Based on the results of the interview above, it can be seen that the respondent used this strategy as an option to increase the use of words and terminologies with the same meaning while presenting his argument, although its use is less grammatically correct in the sentence stated. However, the respondent is still cognisant of other words which are more accurate for conveying the argument. This choice proves the debater's ability in terms of proficiency and vocabulary.

\section{c. Circumlocution}

The findings of the analysis also showed that the respondent chose the circumlocution strategy when debating. Circumlocution is used when a debater defines a topic or is explaining the content of the debate. As mentioned earlier, the debaters obtained information from different languages through various news channels and websites on the internet. In fact there were respondents who were more interested to obtain information from English language websites compared to their mother tongue and Arabic language even though they were participating in Arabic language debate. This was admitted by the respondent who said that:

"So saya prefer la...bahasa Inggeris, sebab bahasa Inggeris... untuk fakta yang kita keluarkan, kebanyakan kita tukar bahasa ni bila ada fakta" (U41: R2)

["So I prefer... English language, ... for the facts we produce, mostly we will change this language when there are facts"]

In this situation, information from various languages will be combined when debating in the Arabic language, and at this point circumlocution strategy will be used.

Based on the observation made by the researcher through the video recording there were respondents who obtained information from websites in languages other than Arabic language such as www.shamela.com in minute 01.01 (MV_5561: R1) and www.beritaharian.com in minute 04.01 (MV_5561: R1). Then, the respondent did the elaboration process. This process involves three skills; which are collecting, analysing and conveying. Most of the information obtained must be filtered and arranged so that the facts put forth do not divert from the idea and objective of the debate topic in competition.

Apart from the use of the circumlocution strategy which involves obtaining information from many languages, the research respondents were also found to have chosen this strategy through the use of analogy to rebut the arguments of the opposing team. This can be seen based on the video recording which was also admitted by the respondent themselves during the interview session:

"... Tetiba saya terfikir pasal analogi ni sebab bagi saya aa analogi ni adalah salah satu cara berkesan jugak nak bidas secara logik aa..." (U57: R3)

["... Suddenly I thought of this analogy because for me this analogy is one of the effective ways to logically rebut ..."]

Among the analogies used is the cartoon character, Doraemon. The circumlocution strategy through this analogy is to defeat the argument of the opponent, as mentioned by the third respondent in the third minute (MV_5563): 


$$
\text { "نحن ليس دوريمون، لا نستطيع أن نضمن عن المستقبل" }
$$

which means "We are not Doraemon who is able to predict what will happen in the future"

In stating the choice for this analogy, the respondent explained that they had experience from previous debating sessions when the opponent used it and was able to attract the attention of the audience to the argument raised:

"...di sidang dua, aa sebelum kami berjumpa dengan UM, kami jumpa dengan UIA, aa dia menggunakan satu kalimah..., kami bukannya Doraemon iaitu kami ada poket ajaib untuk meramal masa depan, dan jugak, kami ni jugak, tak nak jadi seperti Nobita, yang takut untuk menghadapi masa akan datang... dan, dan di situ kita dapat lihat bagaimana bahasa itu dapat memainkan peranan dalam menarik warga dewan untuk terima usul pembawakan kami" (U18: R1) ["...in the second sitting, before we met with UM, we met with UIA, they used a phrase ... we are not Doraemon that we have a magic pocket to forecast the future, and also, we too, do not want to be like Nobita, who is afraid to face the future ... and there we can see how language can play a role in attracting the audience to accept the motion we raised"]

Besides that, the debaters also chose the circumlocution strategy by restructuring what was stated by the opponent as recorded in minute 01.11 (MV_5562: R2). The respondent had restructured the opponent's argument when he started the debate with the phrase such as; قد قالت المعارضة (The opposing team has stated), or قد ادعت المعارضة (The opposing team has claimed).

\section{3) Transfer Strategies}

In this research, the data analysed showed that the debater had chosen four types of transfer strategies, which are translation, appeal for assistance, language switch as well as mime.

\section{a. Translation}

According to Tarone (1980), the translation strategy only involves literal translation, however in this research the researcher found that the debater had used the literal translation and contextual translation, as well as a combination of the two simultaneously.

\section{Literal Translation}

A literal translation or also referred to as a direct translation is defined as a process of changing word by word directly without taking into account the context and the entire sentence. In debating, the one who holds the office of the Prime Minister is tasked with defining each word found in the topic or the motion being debated. At this time, he will usually refer to the dictionary, and then during the debate, he will translate the definition into the Arabic language by using the literal translation strategy. This can be seen in the video recording which showed the first debater had defined each word literally (MV_5561: R1, minute 01.44). This strategy is usually chosen when the debaters are doing their preparations before the commencement of the debate. 


\section{Contextual Translation}

In the debating process, literal translation only is not enough. In several instances, the debaters also require the skill to explain the definition which was literally translated by applying the translation strategy contextually. In this research, the contextual strategy was used before the debate competition began, which was while carefully preparing for every content of the speech text so that the text produced is complete and informative. This was admitted by the respondent during the interview process:

"Oh... ada yang maklumat tu, saya bukak dan saya ambik perkataan tu sebijik mengikut apa yang dikatakan, tapi kita cantikkan dengan gaya bahasa yang aa bertukar sikit, dengan gaya bahasa yang lebih sistematik dan tersusun." (U16: R1)

["Oh ... there is some information, I opened and I took the word exactly according to what was said, but we embellish it with the language style that changed a bit, with a style of language that is more systematic and in order."]

Based on the respondent's view above, it can be understood that a debater's skills in language is very important when they choose this translation strategy. This is because they have to transfer whatever information, regardless of which language whatsoever to the Arabic language with their own language style, so that the information is able to support their argument, and the process of understanding for the jury and the audience is carried out and effective.

The contextual translation strategy is not only chosen in preparing the text before the debate, in fact they also use it spontaneously when delivering their argument based on the information prepared beforehand in their mother tongue. This can be seen based on the results of the interview with the respondent who was the third debater in the competition:

"... bila dah makin lama pegang orang ketiga ni, saya pun terfikir aa, baik saya buat camne yang saya faham untuk saya balas, .... Apa yang saya sedia dalam bahasa melayu, saya irtijal [spontan] on the spot balas dengan ayat bahasa Arab, tapi aa effect dia adalah stuttering, tu yang hunaka hunaka [tergagap-gagap] aaa, dia jadi macam... sebab benda tu on the spot nak bina ayat tu, on the spot dia jadi macam ter aa gagap sikit lah ..." (U54: R3)

["... having been the third person for so long, I also thought, it would be good for me to do it how I understand for me to reply, .... What I prepared in the Malay language, I irtijal [spontaneously] replied on the spot with the Arabic language sentence, but the effect is stuttering, that's why hunaka hunaka [stuttering], ... because on the spot to build that sentence, on the spot makes it stutter a bit ..."]

Based on what was stated by the respondent in the above, although this strategy helped him convey the idea, but usually he will stutter a bit while speaking, especially when translating the word or sentence structure which is seldom or never used previously in presentations. Although this stuttering detracts from the style of the presentation, he still succeeded to do the translation in a short amount of time.

\section{Combination of Literal and Contextual Translations}

The results of the analysis also showed that the debaters also combined both these translation strategies when delivering their arguments. They translate into Arabic language the word that is already understood. Then, the word is included in the argument or reply that they composed earlier in the Malay language. After that, during the debate they will do 
contextual translation. This can be seen through the respondent's reply in the interview session:

"...aa sebenarnya masa saya tulis dalam bahasa Melayu nak buat radd [hujah balasan] tu perkataan tu dah kita dah... Maksudnya benda tu kita dah tahu dalam bahasa Arab..." (U55: R3)

["...actually when I wrote in the Malay language to do the radd [responding argument] that word we already... Meaning we already know that in the Arabic language ..."]

The respondent also stated that this strategy requires a high level of understanding and confidence, apart from the requirement to master language skills so that their argument is effective. This was explained by the respondent as follows:

"...bagi saya berkesan, sebab saya faham apa nak cakap. Aaa lagi satu... bagi saya perlukan maharat lughah lah [kemahiran bahasa], ... and lagi satu saya kena yakin maksudnya..." (U55: R3)

["...for me to be effective, because I understand what to say. another thing ... for me it requires maharat lughah [language skills], ...and another thing I must be confident of its meaning ..."]

He further added:

"...apa yang saya nak cakap tu saya kena yakin betul-betul, pastu saya boleh sampaikan dalam bahasa Arab" (U66: R3)

["...what I want to say is that I have to be really confident, then I can convey in the Arabic language"]

This strategy also requires the debater to master the grammar well, as well as be willing to repeat the speech made when there is an error in this aspect, as per the following response: "...saya memang berusaha betul-betul jaga nahu saraf [sintaksis dan morofologi]. Yang keluar on the spot...a'a jaga nahu saraf dalam keadaan on the spot ...atau pun saya ulang balik bila saya tahu saya silap, so saya kena ulang balik, macam tu lah" (U66: R3)

["...I worked really hard to protect the nahu saraf [syntax and morphology]. That came out on the spot ... also protect nahu saraf in the circumstance of on the spot ...or I will repeat when I know I made an error, so I have to repeat"]

In conclusion, both these translation strategies became the choice for the respondents in aiding the speech process. The translation practised may not be accurate in terms of meaning, but effective in protecting their fluency when conveying various ideas and arguments which require a high level of mastery of Arabic language skills.

\section{b. Language Switch}

In this research the language used by the Arabic language debaters throughout the debate was not focused on one language only. They also included words from other languages such as Malay and English with the condition that it is a noun, such as the title of an article, the name of a news website and also terminologies which have to be retained in the original language. This strategy which is used is called the language switch strategy.

Based on the video recording of the respondents' debate presentation, they often chose this strategy. For example, the first respondent started the debate discussion by mentioning the 
name of a website; that is www.shamela.com in minute 01.01 to support his statement (MV_5561: R1). As the old name of the website is in English and the pronunciation is according to the English pronunciation, hence the respondent retained the original pronunciation of the name so that the audience could understand the internet source referred to. Here, the debater had chosen the language switch strategy when he had to intersperse his speech with a language other than the Arabic language.

"... jadi bila kita ambik fakta itu, kebanyakan kita ambik, memang ambik daripada bahasa Inggeris, dan apabila kita tukar jadi bahasa Arab takut orang tak faham, aa...sesetengah perkataan kita kena kekalkan dia punya bahasa tu, supaya mampu beri faham kepada orang ramai" (U34: R1)

["... so when we take this fact, most that we take, definitely take from the English language, and when we change into the Arabic language, people may not understand, ...some words we have to retain its language, so to enable public to understand"]

Based on the interview data, the respondent admitted that he had used this strategy in speech and did not have any problems applying it:

"aaa.. pada saya tak terlalu nih, kesukaran." (U3: R1)

[“.. for me not so, difficult."]

This statement is also supported by the other respondents, as the preparation was done before the competition:

"Lagipun sebab benda tu dah ada persediaan, haa persediaan..." (U49: R3)

["Anyway that was already in the preparations..."]

However, this strategy could not be carried out by all the respondents. There were some difficulties when some of them admitted that the process of language switch is quite disruptive to the fluency of speaking well during the debate:

"Aa, bergantung kepada debater, macam saya... kalau saya sendiri nak tukarkan satu bahasa daripada bahasa Arab ke bahasa Inggeris tiba-tiba tu... sedikit mengganggu saya punya performance tu, sukar sikit lah... jadi ganggu sikit, lidah pun berbelit." (U40: R2)

["depends on the debater, like me ... if I myself want to change a language from Arabic to English suddenly ... will interrupt my performance a bit, so a bit difficult ... so if interrupt a bit, the tongue is tied."]

This clearly shows that not all debaters are able to switch languages while debating. However, for those who have made preparations before starting the debate, this strategy is not too difficult to use.

\section{c. Appeal for Assistance}

The debate activity is a group activity that is evaluated based on the overall performance of the members of the group although each debater has different tasks. However, every debater will definitely face various situations which are difficult and challenging while debating, such as lack of vocabulary, somewhat nervous to appear confident, or stuttering when speaking. To face situations such as these, the appeal for assistance strategy is often used by handing over the task to a team member. 
As the researcher found in the video recording, the first debater who was presenting his argument had shifted his gaze towards his left when the opponent interrupted. The respondent seemed annoyed and paused a while because he was unable to reply to the interruption. He then stated (MV_5561: R1, minute 05.58):

$$
\text { الجواب التي في حجتنا... بعد.. هذا }
$$

[The response is in our next argument]

Clearly, the analysis showed that the respondent was unable to respond to the interruption and gave the responsibility for answering the question presented by the opponent to his team mate who will be presenting the next argument. When asked during the interview session, he replied that he was confident his team mate would be able to complete the task by saying: "Pertamanya kawan saya ni er... dah ada jawapan. Yang kedua, yang tu pun ada termasuk dalam hujah dia aa... ada kaitan dengan hujah yang dia akan bawak." (U33: R1) ["Firstly this friend of mine... already has the answer. Secondly, that is included in his argument... it is related to the argument that he will be presenting."]

The researcher views that the stressful situation caused the respondent to be unable to reply well to the question posed by the opponent, however choosing the appeal for assistance strategy is seen as effective because the team mate will be prepared to answer when presenting the argument that will be done later.

\section{d. $\quad$ Mime}

In a debate competition, the movement of several body parts during the debate is also important in the effort to attract the attention of the jury. Merely saying the words without any movement will result in a lacklustre presentation. Based on the video and the interviews which were analysed, the researcher found that the research respondents used the mime strategy in two forms; which are changes in facial expression and tone of voice as well as body movement.

\section{Change in Expression and Tone of Voice}

Through the video recording data, the researcher found that the three respondents made full use of expressions as well as their tone of voice as a way of conveying information effectively to the audience. The first respondent for example changed his expression according to the situation in conveying the information (MV_5561: R1). At the beginning of his speech, he began with a serious expression when defining the words that were found in the motion presented. In the middle of the speech, his expression changed to be more relaxed. Most interesting was when he faced difficulties pronouncing the word 'bakäluriyus', his expression was almost as if unaffected by the situation, in fact his tone of voice remained energetic and his speech continued smoothly, as though no problems occurred. During the interview, he admitted the error:

"Saya agak-agak je. Saya cakap je apa... salah kan?.." (U8: R1)

["I just guessed. I just said it ... it was wrong wasn't it?..."]

The second respondent chose the mime strategy which involved gazing with a serious expression. He often looked towards the jury and the audience throughout the debate, especially when changing the argument from one idea to another idea (MV_5562: R2). The third respondent used different expressions when responding to interruptions and questions 
raised by the opposing team. At the early part of the speech, his expression was more stable with a more relaxed tone of voice. However, at the end of the presentation, as he was interrupted by the opponent, his mime strategy which used a serious expression as well as a pressing tone managed to weaken the opponent so as to accept the reply given (MV_5563: R3).

\section{Mime and Body Part Movement}

The results of the analysis of the video (MV_5561: R1) (MV_5562: R2) (MV_5563: R3) for the three respondents showed that they maximised mime and hand movements while debating. They also changed their body positions accordingly to attract the attention of the listener. When interviewed, they admitted that mime and body movements greatly helped in further explaining their arguments:

"...ada pergerakan daripada tangan tu jugak yang membantu dalam memainkan peranan aa... menjelaskan apa yang kita cakap, maksudnya kalau kita cakap Arab pun, orang yang tak boleh nak faham agak agak dia boleh teka, macam tengok gaya pun macam boleh faham kita, contoh macam 'kullu' (sambil membuka tangan) haa dia macam 'keseluruhannya'. Haa macam tu lah... walaupun orang tu tak kuasai bahasa Arab tapi dia boleh tahu melalui kita punyai body contact tadi" (U6: R1)

["...there are movements by hand which also help in playing a role ... explaining what we are saying, meaning if we were to speak in Arabic, the one who cannot understand can maybe guess, like looking at the style maybe can understand us, for example 'kullu' (while opening the hands) it is like 'entire'. ... although that person has not mastered Arabic but he can know through our body contact [language] just now."]

There were respondents who stated that their mime and body part movements were able to further smoothen their presentation and style of speech, in fact this strategy would increase their confidence while debating as the following words:

"saya pun bukan jenis yang keluar sangat tangan semua, sebab macam saya, saya kena tengok apa yang saya nak cakap, tapi bila terkeluarnya tangan tu betullah... dia macam bantu saya untuk lancarkan lagi. Kalau saya diam, dia macam tak leh... Dia akan menyukarkan saya untuk saya sampaikan perkataan tu. Lagi satu dia macam konfiden sikit lah bila ada tangan $n i^{\prime \prime}$ (U53: R3)

["I am not the type to hold out my hands and everything, because for me, I have to see what I want to say, but when the hands come out, it is true ... it is like it helps me to be more fluent. If I stay still it is as if I cannot... It makes it difficult for me to say the word. Another thing, it is as if more confident when using the hands"]

In conclusion, choosing the mime strategy is one of the common practices among the debaters to smoothen speech, emphasise the argument as well as increase the confidence level when speaking. This means that in debate competitions a debater not only focuses purely on expressing the words, but attention must be given to how to convey the words with creative body language and mime that is appropriate to the situation while debating.

\section{4) Repetition Strategy}

This repetition strategy is a new finding which was obtained while doing the analysis on the respondents' data transcription. This repetition strategy is meant as one of the oral communication strategies which is performed repeatedly. Actually, when a debater is 
standing up to begin his speech, he is also fighting with various negative internal feelings, such as probably not being ready or nervousness and not very confident when speaking. Therefore, this strategy is chosen by the respondents to control and overcome this deficiency when it comes to their turn to debate.

In the recording data which was analysed, the first respondent was seen as often repeating the phrase "Ayyuha al-muhtarimun al-kiram" (All esteemed ones). When asked why he did that, he answered:

"... untuk menarik perhatian a'dho'ul barlaman [ahli dewan] itu sendiri." (U4: R1)

["... to attract attention of $a^{\prime} d h o^{\prime} u l$ barlaman [audience in the hall] itself."]

When asked further regarding the importance of attracting attention at that time the following is the reply by the respondent:

"... kami nak seluruh dewan tu menerima apa yang kami nak bawakkan. Dan percaya dengan apa yang kami nak bawak. Dan kami nak biar betul-betul diorang fokus tentang sebenarnya apa tujuan kami nak bawak benda ni, dan jugak kebaikan dia..." (U5: R1)

["... we want the entire hall to accept what we are about to deliver. And believe in what we will deliver. And we want them to really focus on what is actually our purpose in delivering this, and its advantages..."]

This shows that the respondent chose this strategy not only to attract the attention of the audience, but every time this exclamation phrase is repeated, there is an implied meaning behind it, which is to make the audience aware about the sequence of the speech that is about to be put forth. This process is important in the debate competition, as the winning factor in a competition is not only based on how successfully a team delivers accurate facts and arguments, but also their ability in attracting the attention of the jury and the audience. Hence this coincides with the meaning of the debate itself, which is to always persuade and redirect attention to the content of the speech of the debaters.

In the debate speech content, a debater has to alternate with several strategies so that his presentation is not only in the form of a normal presentation. The existence of different variations in the speech is very much required to balance content, examples and also explanations so that the presentation is not monotonous and boring. Another action done by the respondents when wanting to move from one argument plot to the content of the explanation as well as giving examples is by using the exclamation phrase such as أيها الجمهور (Esteemed audience) or أعضاء البرلمان الكرام (Revered audience). This phrase is stated repeatedly so as to make those present aware about the shift in each phase while debating, as stated by the respondent:

"...fungsi a'dho'ul barlaman [anggota dewan], jumhuuranal karim [penonton yang dihormati], sebenarnya adalah sebagai pemisah, maksudnya pemisah gerak kerja, contoh, berpindahnya daripada takrif, daripada qhodiyyah [isu] kepada takrif, maksudnya nak masuk hujah, setiap tu kita kena selit a'dho'ul barlaman [anggota dewan]... jumhuurunal karim [penonton yang dihormati]. Macam kena sedarkan balik semua orang haa... macam kita dah masuk gerak kerja baru aa... dah masuk part baru, dan orang dengar dia tak perasan kot, mungkin dengar tak perasan." (U5: R3)

["...the function of $a^{\prime} d h o^{\prime} u l$ barlaman [audience in the hall], jumhuuranal karim [esteemed audience], is actually as a separator, meaning separating activity, example, moving from 
definition, from qhodiyyah [issue] to definition, meaning about to enter argument, every one of that we have to insert $a^{\prime} d h o^{\prime} u l$ barlaman [audience in the hall]... jumhuurunal karim [esteemed audience]. It is as if we have to make them aware again ... like we have moved to a new activity ... entered a new part, and maybe those that heard they did not realise, maybe heard but did not realise."]

There were also those among the respondents who assumed the phrase as a place to rest: "Macam saya sendiri, saya sebut tu sebagai tempat saya berehat.. aa tempat berehat.. sebab saya cakap banyak-banyak, a'dho'ul barlaman [anggota dewan], saya cakap dengan nada yang tenang, haa.." (U5: R1)

["For me, I say that as a place for me to rest.. resting place.. because I speak a lot, a'dho'ul barlaman [audience in the hall], I say in a calm tone,.."]

This proves that the repetition strategy chosen by the debaters during the competition is for the purpose of attracting the attention of the audience to the content that is to be delivered, to be the separator for each phase in the speech, as well as to give room for them to rest for a moment. All these functions are centred around the same objective, which is to ensure that they are able to speak well in the Arabic language when debating.

\section{Conclusion}

To conclude, the results of this research proved that the Non-Arabic debaters adopted the oral communication strategies of avoidance, paraphrase and transfer. They preferred the strategies of message abandonment, topic avoidance and appeal for assistance when lack of time and they were unable to face the arguments of the opponents. When faced with language constraints, approximation and word coinage strategies were used. Literal and contextual translation, as well as language switch strategies are often chosen in preparation for debating, while circumlocution and mime strategies were preferred in order to reinforce an argument and increase confidence. It was noted that a good mastery of grammar is a prerequisite to enable selection of the appropriate translation strategy. The study also found that debaters preferred a new strategy that was not in theory; which is named as repetition strategy. This new strategy which was in the form of an exclamation phrase was found to be frequently used by the three respondents of the research with three different functions; either to attract the attention of the audience, moving from one argument to the next argument or to momentarily rest the mind.

It is suggested that future research related to the debate strategies which use Communication Strategies Theory by Tarone (1980) as the theoretical framework for analysis ought to be combined with other theories. This is due to the latest findings in this research; that is the repetition strategy, which is not listed in the theory but was preferred.

The findings of this research suggest a structured training for Non-Arabic debaters that is focused on a more systematic oral communication strategies can be inculcated in them during the practice sessions. This comprehensive and focused training is important to train the debaters to use various strategies, and therefore to be able to choose the accurate and effective strategy while competing. At the same time, this type of training will also be greatly beneficial in helping the debaters build their confidence and improve their command of Arabic language to overcome the problem of weakness in speech as proven in past research. 


\section{References}

Abd Rahman, G. Y., Nik Yusoff, N. M. R., M. Shah, P., Wah, W. H., \& Sahrir, M. S. (2012). Penggunaan bahasa Arab lisan dan hubungannya dengan strategi pengurusan sumber. GEMA Online Journal of Language Studies. 12(2), 505-520.

Abu Bakar, K., \& Alias, N. A. (2017). Arabic debate and world-readiness. International Journal of West Asian Studies. 9(1), 93-106.

Aladdin, A. (2012). Analisis penggunaan strategi komunikasi dalam komunikasi lisan bahasa Arab. GEMA Online Journal of Language Studies. 12(2), 645-666.

Alias, N. A. (2018). Sumbangan debat kepada pemerolehan bahasa kedua: Teori Output Desakan dan pendekatan kefasihan [Unpublished master thesis]. Universiti Kebangsaan Malaysia.

Arshad, M., \& Abu Bakar, K. (2015). Penggunaan strategi pembelajaran aturan kendiri kemahiran bertutur bahasa Arab dalam kalangan pelajar Melayu di Pusat Asasi UIAM. ASEAN Journal of Teaching and Learning in Higher Education. 7(1), 1-17.

Asbulah, L. H., Lubis, M. A., Aladdin, A., \& Sahrim, M. (2020). The level of students' engagement in Arabic within public universities. Asia Pacific Journal of Educators and Education. 35(1), 1-16.

Che Haron, S., Ahmad, S. I., Mamat, A., \& Mohamed, I. H. A. (2010). Understanding Arabicspeaking skill learning strategies among selected Malay learners: a case study at the International Islamic University Malaysia (IIUM). Contemporary Issues in Education Research. 3(8), 9-20.

Daud, N., \& Abdul Pisal, N. (2014). Permasalahan pertuturan dalam bahasa Arab sebagai bahasa kedua. GEMA Online Journal of Language Studies. 14(1), 117-133.

Hamzah, A. (2018). Kebimbangan bahasa guru pelatih terhadap pembelajaran kemahiran bertutur bahasa Arab dan kaitannya dengan strategi pembelajaran [Unpublished doctoral thesis]. Universiti Putra Malaysia.

al-Hujuri, S. I. (2019). Tawẓîf al-munāẓarat fi ta'līm al-'Arabiyyah li al-nātiqīn bi-ghayrihā: Dirāsat wasfiyyah tahlīliyyah. al-Tajdīd. 23(46), 99-147.

Ismail@Yaakub, A., Che Mat, A., \& Pa, M. T. (2012). Membina kemahiran pertuturan menerusi aktiviti lakonan dalam pengajaran bahasa. GEMA Online Journal of Language Studies. 12(1), 325-337.

Mohamad, Z., Embi, M. A., \& Nik Yusoff, N. M. R. (2010). Strategi pembelajaran bahasa Melayu dan Inggeris pelajar cemerlang. Bangi: Penerbitan Fakulti Pendidikan, Universiti Kebangsaan Malaysia.

Kiram, M. N., \& Abdul Rahim, N. A. (2018). Teknik perundingan dalam Pertandingan Debat Diraja. Jurnal Linguistik. 22(1), 032-048.

Morse, K. G. (2011). Debate: A tool for language learning. Journal of Border Educational Research. 10(Fall), 108-119.

Omar, H. (2015). Pengaruh perbezaan indvidu terhadap penguasaan bahasa Arab dalam kalangan pendebat di universiti awam Malaysia [Unpublished master thesis]. Universiti Putra Malaysia.

Radzi, P. M., Mezah, C. R., Mustapha, N. F., \& Aziz, M. A. (2015). al-Akhtā' al-shā'i'ah fi nutq ba'd al-aswāt al-'Arabiyyah ladā thullāb al-jāmi'at fí Māliziyā. Global Journal alThaqafah. 5(1), 133-144.

Quinn, S. (2010). al-Mursyid fi fann al-munāẓarāt: Namūzaj buțūlat al-'ālami li-munāẓarāt almadāris. Translated by al-Sharafiy, A. J. Qatar: Markaz Munāẓarat Qatar. 
Salami, A. L. (2014). al-Madkhal ilā fann al-munāz̧arat. Qatar: Bloomsbury Qatar Foundation Publishing.

Samah, R., Abdul Hamid, M. F., Sha'ari, S. H., Mohamad, A. H. (2013). Aktiviti pengajaran kemahiran bertutur bahasa Arab dalam kalangan jurulatih debat. GEMA Online Journal of Language Studies. 13(2), 99-116.

Satria, A. P. (2017). Using debate to enhance students' speaking ability as their character building. English Education: Jurnal Tadris Bahasa Inggris. 10(1), 149-163.

Tarone, E. (1980). Communication strategies, foreigner talk and repair in interlanguage. Language Learning. 30(2), 417-428.

Zare, P., \& Othman, M. (2015). Students perceptions toward using classroom debate to develop critical thinking and oral communication ability. Asian Social Science. 11(9): 158-170. 